\title{
Business Succession in Indian Family Businesses in South Africa
}

\author{
Yaaser Mahomed \& Vuyokazi Mtembu \\ University of KwaZulu-Natal, Durban, South Africa \\ yaasermahomed@gmail.com,mtembuv@ukzn.ac.za
}

\begin{abstract}
Family businesses play a pivotal role economically and socially in most countries. The study aimed to identify and understand the experiences of Indian family businesses in South Africa with regard to business succession. A quantitative research approach was used with data collected through Google forms online survey. Data was collected from sixty (60) business people from Indian-owned family businesses in South Africa. The study interrogated the following factors which have an influence on family business succession: business ownership influence in succession, business readiness for the exit of owner and succession, the role of the owner after exit from business and selection criteria of the right successor. Findings revealed that the majority of families (86.27\%) said it is important to have a hundred percent or full ownership of the business and that a successor should be selected within the family from their bloodline. Findings also revealed that the majority of businesses $(86.27 \%$ ) were not fully ready for the exit of the owner or current leader of the business and that on the exit of the owner; a majority (90.2\%) of businesses will prefer to have the owner playing an active advisory role in the business. It is recommended that familyowned businesses should plan for succession on time and draft a well-planned strategic succession plan for the business. It is also recommended that an objective criterion be used in selecting a successor who will take the business forward. Healthy business continuity should be the ultimate goal of succession and families should not sacrifice successful business continuity because of their, internal differences and conflict, culture, blood relations, gender or religion.
\end{abstract}

Keywords: Indian Businesses, Family Businesses, Succession planning, Business continuity, South Africa.

\section{Introduction}

There is no one standard definition of what a family business is because of the various factors, complexities and differences within family businesses such as size, percentage of ownership, the environment it operates in and other factors. Kiwia, Bengesi, and Ndyetabula, (2019) define it as a business where family members contribute to its capital and are engaged in its management, and it is intended to be transferred to the next generation. For this paper, a family business is considered as a business whose ownership as well as control is within the founder's family members, the family members are directly involved in the business' daily activities and the plan is to transfer the business to subsequent family generations. Family businesses play a pivotal role in many countries globally. Statistics from the US-Based Family Firm Institute state that; familyowned organizations make up two-thirds of all businesses around the world and they are estimated to contribute $70 \%-90 \%$ of global growth every year but sadly the failure rate of these businesses seems to be high (www.ffi.org). Furthermore, the majority of new jobs, globally, are created through family businesses (Neubauer and Lank, 1998). Succession planning is the process of transferring leadership and power or management from the business founder/or one family member to another family member while maintaining a positive family relationship and business performance (Chaimahawong and Sakulsriprasert, 2013).

Indian family-owned businesses in South Africa are potentially facing a succession planning problem as most fail to effectively plan their succession to ensure business sustainability. The inability for the long-term survival of family businesses can be attributed to a number of factors including; unsuccessful or lack of succession planning among the most key (Lansberg, 1998) and the reluctance of business founders to hand over their creation (Brockhaus, 2004). A study on the business succession of family-owned businesses conducted by Steen (2018) revealed that the first generational transfer is hard and that only thirty percent of family-owned businesses successfully pass the baton from the first generation to the second generation. Overwhelmingly, if one were to go with findings from Steen (2018) and the (ffi.org) this means that familyowned businesses are not setting themselves up for success in transitioning to the next generation/s and business succession is the main culprit that leads to the failure and non-survival of these businesses. Hence, this study aims to determine the effectiveness of business succession in Indian family businesses in South Africa. The objectives of this study were; to determine the level of preparedness for business succession in 
Indian family businesses in South Africa. To investigate how Indian family businesses in South Africa view the different factors that affect business ownership and succession and to closely examine the processes of succession among family businesses in South Africa.

\section{Literature Review}

Business succession has been described as the most crucial decision family businesses have to make (Handler, 1994). Business succession is a process of preparing and grooming family leaders to develop and transfer firm and family knowledge (Chirico and Nordqvist, 2010). It is a constant and ongoing process done over a period of time (Handler 1990). Succession planning is defined by Lansberg (1983) as making the plans and preparations vital to ensure the harmony of the family and the continuity and success of the enterprise through to the next generation, these preparations must be mindful of the future needs of both the business and the family. Chua (1999) through a theoretical framework outlines some of the factors that can influence the planning and implementation of succession in family-owned businesses which must be considered when succession planning is conceptualized and implemented in the family business. According to Chua (1999), some of those factors are; ownership, management, succession, age of business and financial performance of the business. According to Fahed-Sreih (2018), succession planning secures and ensures the availability of knowledgeable, experienced and capable employees that are prepared to assume leadership and other crucial roles as they become available in the business. Hence, an effective succession management mandate is to build potential successors up to and down the entire leadership chain. Despite the significance of succession, information in the scientific body of knowledge indicates that family businesses wrestle to deal with this issue, with a succession of the family CEO being one of the most vexed issues in a family business (Bennedsen, Nielsen, Perez-Gonzalenz and Wolfenzon, 2007).

Research has indicated that many family business leaders fail to effectively plan for succession (Sharma and Rao, 2000), despite the compelling evidence of successful business succession increasing the chances of survival of family businesses. A study by Feltham and Barnett (2005) found that $61 \%$ of family business leaders did not choose a successor and had no plan in place to choose one. One of the key reasons for the hesitance in planning for succession is the uncomfortable emotions generated by the process, together with the reality that it forces one to accept one's impermanence and confront the need for change (Le-BrettonMiller, Miller and Steier, 2004). Choosing a successor is only one aspect of the process, and it is important that a well thought, effective process of succession be established within the family business (Brun de Pontet, Wrosch and Gagne, 2007). In their study on the importance of planning for business succession for the stability and wealth accumulation for South-Asian families in Kenya, Janjuha-Jivraj and Woods (2001) illustrate the negative impact that ineffective transition in succession has on families, often for generations and on all stakeholders including the community and business market for larger businesses. Research has also determined that family business leaders who acknowledge their need to retire and "pass on the baton" are more aware of the need to invest and grow a business worthy of being passed on, even before the transfer takes effect (Diwisch, Voithofer and Weiss, 2009). Ultimately, Brun-de Pontet et al. (2007) recommend that a transparent succession plan needs to be implemented to avoid the risk of ambiguity resulting in conflict and the possible dissolution of the business.

\section{Research Method}

One's approach to research methods qualitative, quantitative or mixed should be informed by the research, question, access to data, and contextual appropriateness (Thurloway, 2014). Having that in mind, the most appropriate research methodology that aligned with the research strategy was the quantitative approach, as it allowed for accurate and efficient collection of quantitative data. Lack of an adequate succession plan is seen as a key reason why many family businesses fail to grow (Cabrera-Suárez, 2005). Therefore, the study adopted a quantitative research methodology. Data was collected via an online survey link created through Google forms and shared via emails with 60 business people who were sampled and invited to take part in the survey. Sample inclusion criteria only allowed that a sample is drawn from South African business people of Indian heritage. A sample was drawn using databases from South African Indian business associations and referrals of earlier respondents. A random sampling technique was used initially, thereafter a snowball sampling technique was employed to reach additional participants and create an adequate sample size 
suitable for statistical analysis. A Likert 5-point scale was used to frame questions in the questionnaire distributed. The study used Cronbach's alpha reliability coefficient value of 0.70 or higher to test the reliability of the quantitative data and factor analysis was the technique used to ensure the validity of the data collected. Excel quantitative analysis software was used to analyze the data collected and descriptive statistics with illustrations in the form of figures and graphs were used to report the results.

\section{Results}

Demographic Details: Respondents' age- In terms of age; $86.17 \%$ of the respondents were between the ages of 18 to 55, while only $13.73 \%$ were over the age of 55. Business Age - It has been identified that the majority of the businesses surveyed were established post-1970 at a total percentage of $71.53 \%$, while $17.47 \%$ of the businesses were established pre-1970. The oldest business surveyed being at a current age of 118 years old. Generation in Business - In terms of generation, a total of $64.7 \%$ of the respondents were first- or secondgeneration members of their family business, while a total of $31.3 \%$ were in the third and fourth generations or higher. Business Industry - manufacturing and trade, wholesale and retail were the industries selected. The Real Estate industry was selected by $7.8 \%$ of the respondents and the remaining respondents were involved in other industries. Annual Turnover - In terms of revenue, 5.9\% had annual revenue of less than R5, 000,000, $84.3 \%$ of businesses surveyed with revenues between R5, 000,000 to R1, $000,000,000$, and only $9.8 \%$ of businesses had revenue exceeding R1, 000,000,000. The number of full-time employees - In terms of employees, around $11.8 \%$ of the firms had less than 6 employees, while $76.4 \%$ had between 6 to 500 employees, and $11.8 \%$ firms had more than 500 employees.

\section{Figure 1: Importance of Full Ownership of Business}

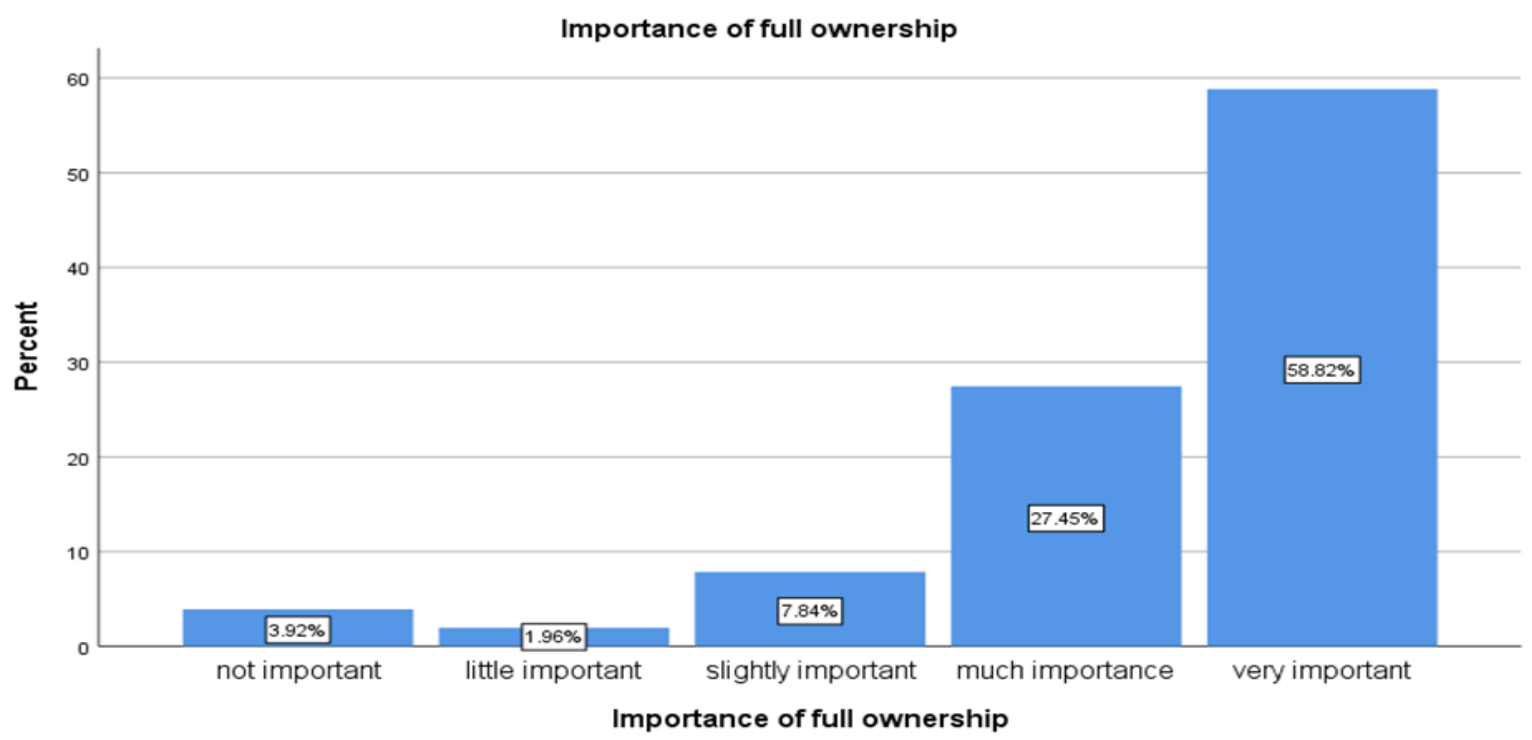

As illustrated in figure 1 above; the majority of the respondents (58.81\%) submit that it is very important to keep $100 \%$ ownership of the business within the family. In a study done by Sharma and Rao (2000), it was reported that the sentiment from the majority of respondents was that; it was very important for Indian business leaders to have a successor from their bloodline. The authors concluded, in their comparison of a typical Indian family and a typical Canadian family, that Canadian family business owners are more willing to pass on their business to a non-family successor than Indian family business owners (Sharma and Rao, 2000). 


\section{Figure 2: Readiness for Retirement of key Family Member}

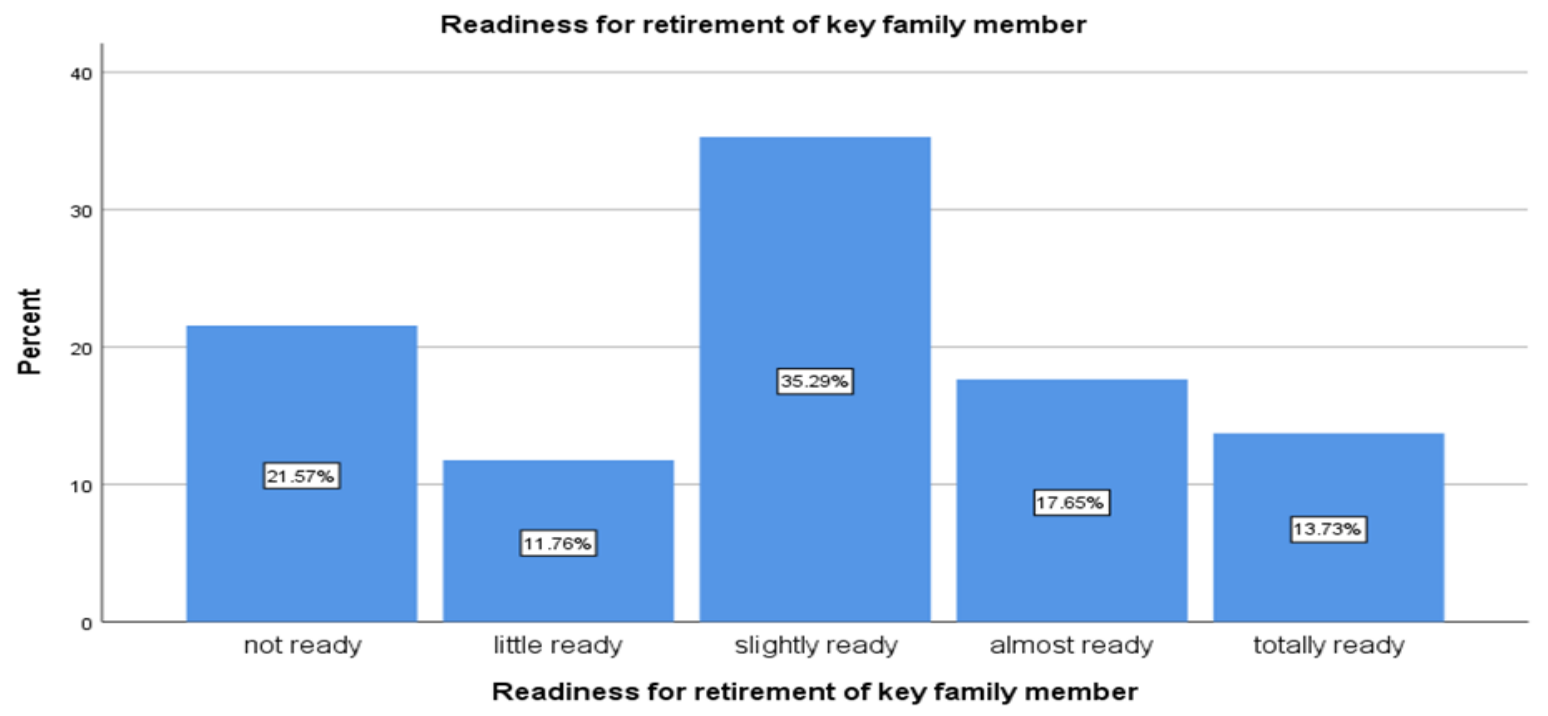

In figure 2 above; $21.57 \%$ of the respondents indicated that their businesses were not ready to cope with the exit or retirement of key members in the business. Also, a significantly large number $(35.29 \%)$ of the respondents indicated that the business is only slightly ready to cope with the exit or retirement of key members and $13.73 \%$ of respondents indicated that the business is ready for retirement and exit of key family member running the business. Miller, Steier and Le Breton-Miller (2003) argue that the higher the preparation level of the possible successor, the higher the likelihood that he or she will take over the family business after the predecessor leaves it. This implies that the processes behind the identification of potential successors and the level of preparedness should begin at least five years before the time of the retirement of key members. Unfortunately, in most family-owned businesses the issue of succession planning seems to be placed at the end of the list of priorities hence the response from most businesses indicates their nonreadiness for the retirement of an owner or key family members leading the business.

\section{Figure 3: Business Readiness for the Next Successor}

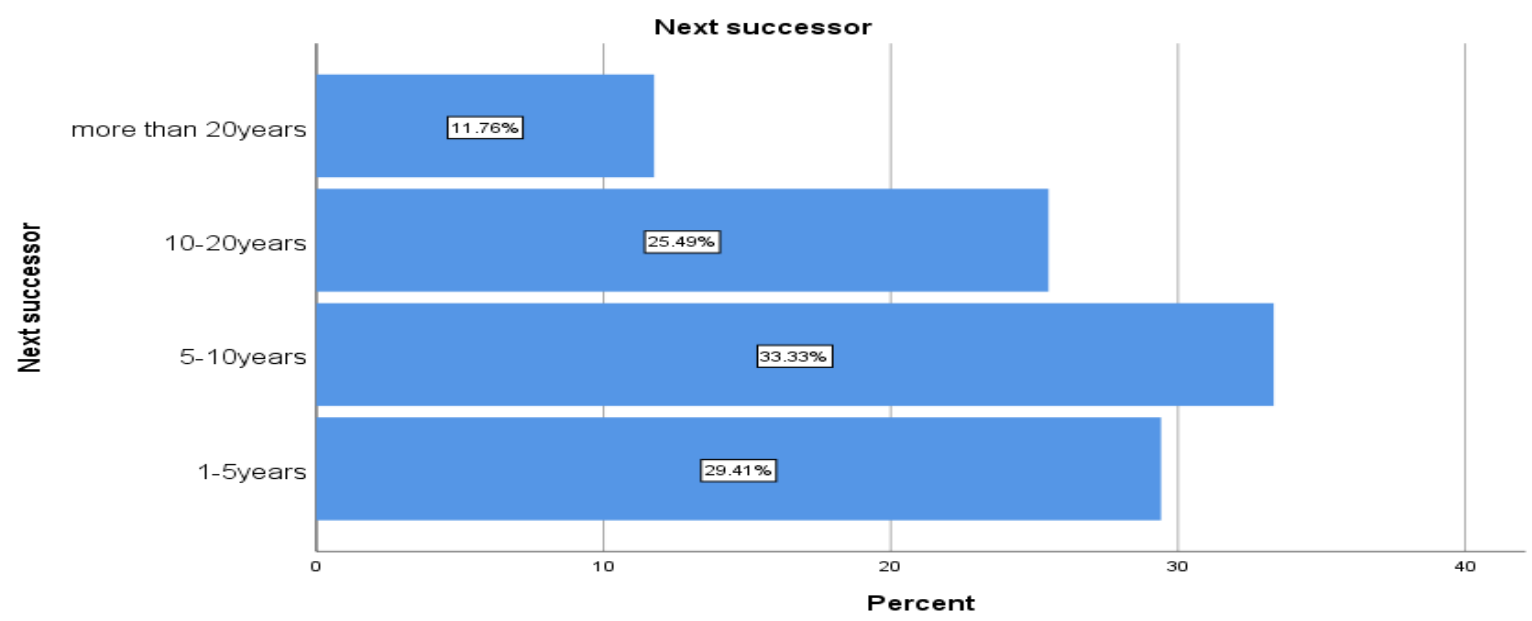

As reflected in figure 3 above; the greatest number of the respondents (33.33\%) stated that their businesses will be ready for a successor in 5 to 10 years, while $29.41 \%$ of respondents stated that their businesses will be ready for a successor soon that is within the next 5 years. There are few businesses $(11.76 \%)$ that indicated readiness in 20 years' time or more. This result is a glimmer of hope for business succession in family-owned businesses as it indicates that although the implementation is not at the level required currently; most 
businesses are aware of the need to prepare for succession and to groom potential successors on time. This indicates that these businesses have the knowledge and understanding of the need to prepare for succession but the problem is the lack of willingness or complacency to do it. Feltham and Barnett (2005) in their study found that $61 \%$ of family business leaders had not chosen a successor nor had a plan to choose one. One of the weaknesses of most business founders is too much attachment to their business to the extent that they do not think of the future of the business in their absence (Kiwia, Bengesi, Ndyetabula, 2019) Miller et al. (2003) found that there is a direct relationship between the preparation level of possible successor and the effectiveness of succession process. The higher the preparation level of a possible successor, the higher the likelihood that he or she will take over the family business after the predecessor leaves it (Miller et al., 2003).

\section{Figure 4: Founder's Role after Successor Take Over}

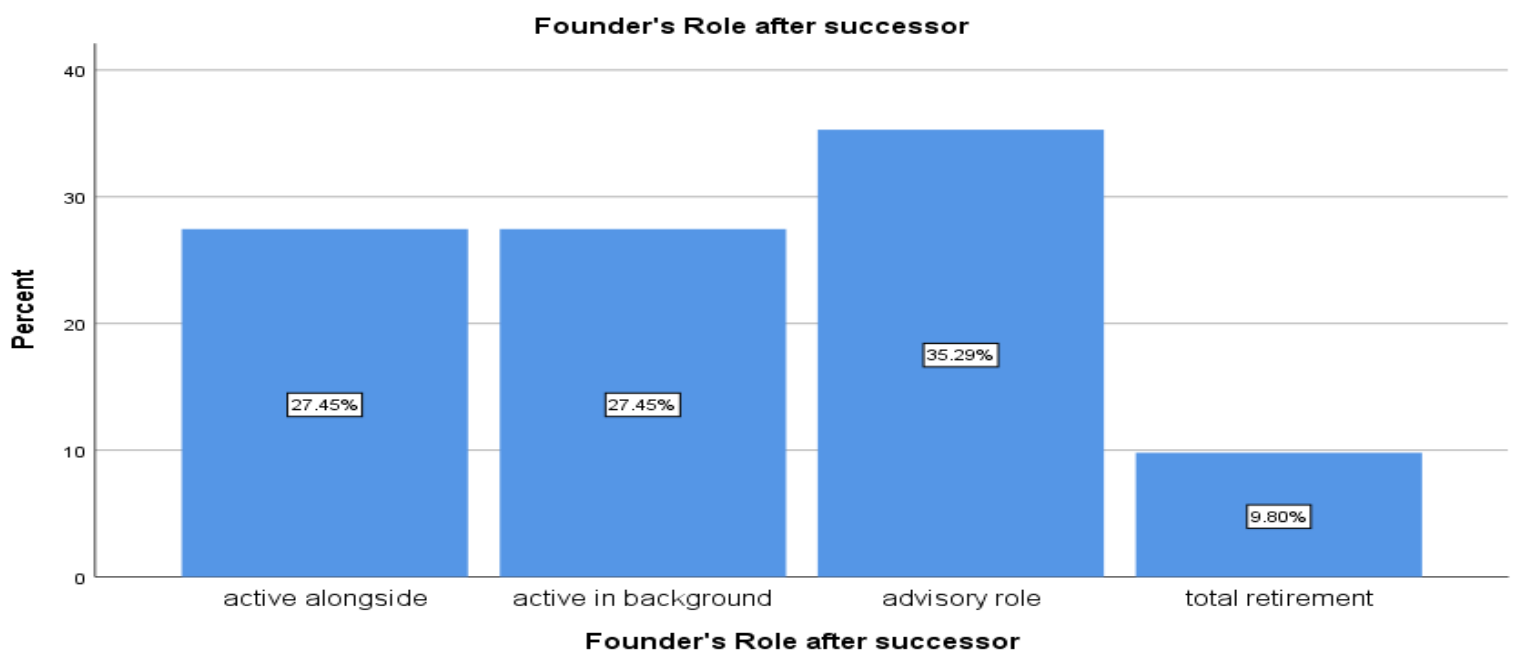

As indicated in figure 4 above; the greatest number of the respondents (35.29\%) submitted that the founder's role will be advisory once the potential successor has taken over while $27.45 \%$ of respondents mentioned that the founder will still play an active role alongside the successor and another $27.45 \%$ mentioned that the founder will be active in running the business in the background. Only $9.80 \%$ of respondents mentioned that the founder will totally hand overall activities and take total retirement. This result is an indication that the majority of Indian family businesses do not feel comfortable with a total retirement option after handing over the reins as they still prefer to have the founder of the previous leader involved in some way either in the background or alongside the newly ordained leader. Studies including those done by Kets De Vries (1977) and Levinson (1971), have found that one of the biggest obstacles to planning for succession is the problems experienced when a founder has to relinquish control. Outgoing leaders, especially founders, are able to ease the transition and handover of power with a family firm (Lansberg and Astrachan, 1994).

Criteria for Potential Successor: A significant number of respondents (39.22\%) submitted that the main criteria for which the potential successor to the business should be chosen must be based on; business acumen, skills and experience. A notable number of respondents $(23.53 \%)$ also stated that a combination of business acumen, skills and education should be the main determinants in choosing the correct successor. Only (3.92\%) stated that education and experience should be key factors in choosing a potential successor. The rest of the respondents stated a number of other factors such as; knowledge, skills, passion and other mix of factors as important. Morris, M., Williams, R., Allen, J. \& Avila, R. (1997) found the level of formal education; training obtained from the incumbent; work experience; entry-level position; the number of years working with the family business before the succession occurs as the main factors that determine the preparation level of the possible successor. This could mean that the level of preparedness for business succession in Indian family-owned businesses in South Africa does not hinge heavily on the readiness of potential successors.

However, Miller et al. (2003) found that there is a direct relationship between the preparation level of possible successors and the effectiveness of the succession process. This in turn implies that there is room for 
improvement in the succession process when it comes to the readiness of potential successors in Indian family businesses. Indian family businesses place importance on the following attributes in a successor: being related by blood, ability to work with and be trusted by family members, business acumen and entrepreneurial risk-taking (Sharma and Rao, 2000). The results in this study indicate that criteria for appointing a successor should be holistic by looking at a variety of competencies that the individual possesses to take the business forward. This indicates that a standalone trait such as 'motivation' or 'education' alone is not enough to qualify one to take over business leadership, more competencies over and above education, motivation and experience are required to ensure that the best successor is appointed. Business acumen was indicated as one of the key competencies required in the selection of the best business successor.

Female Successor Possibility: A significant number of respondents (84.31\%) stated that a female family member can be the successor of their family business and only $15.69 \%$ of respondents objected to the idea of having a female successor. This is also another notable milestone in the mindset shift of Indian businesses whose long-standing traditional norm has been to select only males as business successors and leaders. This is indeed a paradigm shift. In a study conducted by Virick and Greer (2012), it was found that the nomination of female successors was positively associated with the performance of incumbent managers who nominated them as their successors. This implies that lower-performing incumbents were less likely than higherperforming incumbents to nominate women as successors when the diversity climate was unfavorable. When the diversity climate was favorable, lower performers were more likely and higher performers were equally likely to nominate women as successors (Virick and Greer, 2012). Bozer, Levin and Santora (2017) found that the stereotypical attributes of gender associated with women, such as nurturing and family-orientated tendencies, can compromise a daughter's ability to assume the leadership position in a family business hence families need to introspect and objectively deal with such stereotypes to ensure fairness in the process of selecting candidate successors.

Successor Not Identified Within Family: The majority of the respondents, 58.82\%, stated that should their business not find a suitable successor within the family, they would consider having a non-family leader appointed to run the business and $41.18 \%$ stated that in cases where there is no suitable family member available to take over the business they will choose the option to sell the business. This result indicates that there is a slight shift in the long-standing conventional norm, belief and sentiment that only persons related by bloodline should be successors to lead Indian-owned family businesses. This might also indicate that most Indian families owning a business are realizing that the health, success and continuity of the business should be the priority and ultimate goal when choosing a successor over and above whether a person being chosen is related by blood or not.

\section{Discussion}

Indian family businesses in South Africa face similar issues and environments that have been seen in family businesses and in particular, Indian family businesses globally. Indian family businesses in South Africa consider it crucial to maintain a hundred percent control within the business, and most have found it fairly easy to maintain control of their family business. In a study done by Sharma and Rao (2000), it was also revealed that it is very important for Indian business leaders to have a successor from their bloodline and to keep full ownership of the business. The experiences of past policies of apartheid in South Africa, which for years were discriminatory against persons of color, including Indians in South Africa, could be seen as an incentive for Indian family businesses to prosper, survive and grow. Contrary to early research, which strongly showed a preference of the eldest son taking over the family businesses (Churchill and Hatten,1987) in this study most businesses stated that females in the family could be successors of their business. It was determined that most family firms are unprepared for the process of succession planning and most businesses had not identified a successor. Feltham and Barnett (2005) in their study found that $61 \%$ of family business leaders had not chosen a successor nor had a plan to choose one. Those that had identified a successor considered business acumen, business skills, experience within the business, education and motivation to succeed as the most important attributes in a potential successor.

Indian family businesses place importance on the following attributes in a successor: being related by blood, ability to work with and be trusted by family members, business acumen and entrepreneurial risk-taking 
(Sharma and Rao, 2000). Interestingly, the often-cited birth order and gender were identified as an attribute of little importance. The study also found that family businesses that had begun the process of succession planning were more confident in the event of an exit or retirement of a key family member than businesses that have not done any succession planning. Furthermore, those family businesses that had a common vision, showed more consistent levels of communication in the business, which is crucial for effective succession planning. It is therefore recommended that; family businesses should always try to maintain the degree of control they have in the business when transitioning from one generation to the next, as this has a strong bearing on the types of succession planning alternatives available to them. Successor pipelines should be created by assessing the current performance of successors with their future potential to ensure that generational transitions brought about by the exit of key members are handled smoothly. Family businesses should not sacrifice hiring new employees and leaders even if they are not blood-related or introducing new product portfolios just to maintain a degree of family control within the business. A shared vision for innovation is a strong foundation that will ensure open lines of communication and effective transitions from one stage of business succession to the next.

Family businesses should design succession plans based on merit and not nepotism, bloodline, culture, religion or gender. The likelihood of appointing a female successor also depends mainly on whether a climate for diversity exists within the family business or not; therefore, family businesses should strive to foster diversity within their enterprises. Family businesses should try to be more objective in choosing the successor and decide more aligned with ensuring the healthy continuity of the business rather than based on past history, culture, internal family conflicts, gender or even religion. Potential successors should be humble and more prepared to learn from the outgoing leader from an entry-level position rather than being placed into a CEO position without adequate training and preparation. The outgoing leader should find a way to transfer their charisma and differentiated vision as part of the readiness and identification of potential successor process. Family business continuity is one of the biggest concerns with regards to the future of family businesses and it is the responsibility of the outgoing leader to ensure that for the sake of future continuity the business is left in the right hands and for the right reasons. Hence, the processes behind the identification of potential successors and the level of preparedness should begin at least five years before the time of the retirement of key members. Overall, it is recommended that family-owned businesses should plan for succession on time and draft a well-planned strategic succession plan for the business.

\section{Conclusion}

The study aim was to identify and understand factors impacting succession in Indian family businesses in South Africa as well as experiences of these businesses on succession. Findings revealed that Indian family businesses in South Africa face similar issues that have been seen in family businesses, and in particular, Indian family businesses, globally. It was determined that most family firms are unprepared for the process of succession. The implications of this unpreparedness contribute to the non-survival of some of these familyowned businesses. Hence the recommendation was; to ensure healthy and successful business continuity, Indian family businesses need to recognize that a good strategic succession plan needs to be prepared on time, communicated with all relevant stakeholders and be implemented accordingly. This study also revealed that conventional and traditional beliefs that successors should only be male and be from the family's bloodline can be both beneficial and detrimental for business success and continuity. Hence the suggestion that families should be objective in succession decisions and should treat each business according to its unique merits. Further studies are required to look at more factors impacting succession in Indian family businesses.

\section{References}

Bennedsen, M., Nielsen, K. M., Pérez-González, F. \& Wolfenzon, D. (2007). Inside the family firm: The role of families in succession decisions and performance, 111(1), 647-691.

Bozer, G., Levin, L. \& Santora, J. C. (2017). Succession in family business: multi-source perspectives. Journal of Small Business and Enterprise Development.

Brockhaus, R. H. (2004). Family business succession: Suggestions for future research. Family Business Review, $17(2), 165-177$. 
Brun de Pontet, S., Wrosch, C. \& Gagne, M. (2007). An exploration of the generational differences in levels of control held among family businesses approaching succession, Family Business Review, 10(4), 337354.

Cabrera-Suárez, K. (2005). Leadership transfer and the successor's development in the family firm. The Leadership Quarterly, 16(1), 71-96.

Chirico, F. \& Nordqvist, M. (2010). Dynamic capabilities and trans-generational value creation in family firms: The role of organizational culture. International Small Business Journal, 18(5), 487-504.

Chaimahawong, V. \& Sakulsriprasert, A. (2013). Family business succession and post succession performance: Evidence from Thai SMEs. International Journal of Business and Management, 8(2), 19.

Chua, J. H., Chrisman, J. J. \& Sharma, P. (1999). Defining the Family Business by Behavior. Entrepreneurship theory and practice, $13,19-40$.

Churchill, N. C. \& Hatten, K. J. (1987). Non-market-based transfers of wealth and power: A research framework for family businesses. American Journal of Small Business, 11(3), 51-66.

Diwisch, D. S., Voithofer, P. \& Weiss, C. R. (2009). Succession and firm growth: Results from a non-parametric matching approach. Small Business Economics, 31(1), 45-56.

Fahed-Sreih, J. (2018). Conflict in Family Businesses. Palgrave Macmillan

Family Firm Institute. (2009). Global data points. Retrieved 16 August 2016, from http://www.ffi.org.

Feltham, T. S., Feltham, F. \& Barnett, J. J. (2005). The dependence of family businesses on a single decisionmaker. Journal of Small Business Management, 17, 158-170.

Handler, W. C. (1990). Succession in Family Firms: A Mutual Role Adjustment between Entrepreneur and Next-Generation Family Members. Entrepreneurship Theory and Practice, 15(1), 37-51.

Handler, W. C. (1994). Succession in family business: A review of the research. Family business review, 7(2), 133-157.

Janjuha-Jivraj, S. \& Woods, A. (2001). Succession Issues within Asian Family Firms: Learning from the Kenyan Experience. International Small Business Journal, 10(1), 77-94.

Kets De Vries, M. F. R. (1977). The Entrepreneurial Personality: A Person At The Crossroads. Journal of Management Studies, 14(1), 34-57.

Kiwia, R. H., Bengesi, K. M. \& Ndyetabula, D. W. (2019). Succession planning and performance of family-owned small and medium enterprises in Arusha City-Tanzania. Journal of Family Business Management.

Lansberg, I. \& Astrachan, J. H. (1994). Influence of Family Relationships on Succession Planning and Training: The Importance of Mediating Factors. Family Business Review, 7(1), 39-59.

Lansberg, I. I. S. (1983). Managing Human Resources in Family Firms: The Problem of Institutional Overlap. Organizational Dynamics, 11(1), 39-46.

Lansberg, I. I. S. (1988). The Succession Conspiracy. Family Business Review, 1(1), 119-143.

Levinson, H. (1971). Conflicts that plague family businesses. Harvard Business Review, March-April, 90- 95.

Le Breton-Miller, I., Miller, D. \& Steier, L. P. (2004). Toward an integrative model of effective FOB succession. Entrepreneurship theory and practice, 18(4), 305-318.

Miller, D., Steier, L. \& Le Breton-Miller. (2003). Lost in Time: Intergenerational Succession, Change, and Failure in Family Business. Journal of Business Venturing, 18(4), 513-531.

Morris, M., Williams, R., Allen, J. \& Avila, R. (1997). Correlates of Success in Family Business Transitions. Journal of Business Venturing, 11(5), 385-401.

Neubauer, F. \& Lank, A. G. (1998). The Family Business: Its, Governance for Sustainability, London: McMillan Press.

Sharma, P. \& Rao, A. S. (2000). Successor attributes in Indian and Canadian family firms: A comparative study. Family Business Review, 13(4), 313-330.

Steen, A. (2018). Family-owned businesses and our national economy' Retrieved 03 October 2018, $<$ https://www.familyownedbusinessadvisors.com/1018/04/family-owned-businesses-and-ournational-economy/>

Thurloway, L. (2014). Management research challenge: Selected readings. Sage.

Virick, M. \& Greer, C. R. (2012). Gender diversity in leadership succession: Preparing for the future. Human Resource Management, 51(4), 575-600. 